\title{
$X$-ray imagery and physical core logging as a proxy of the content of sediment cores in cold-water coral mound provinces: a case study from Porcupine Seabight, SW of Ireland
}

\author{
A. Foubert · D. Van Rooij · D. Blamart • \\ J.-P. Henriet
}

Received: 31 December 2003 / Accepted: 12 March 2006/ Published online: 24 May 2006

(C) Springer-Verlag 2006

\begin{abstract}
Three provinces, characterized by the presence of carbonate mounds interpreted as coldwater coral banks have been reported in Porcupine Seabight, SW of Ireland and were recently subjected to many detailed studies. This contribution discusses the use of X-ray imagery and physical properties in deciphering palaeoceanographic, sedimentological and biological processes. Physical property core logging and X-ray imagery are used to identify and describe sedimentation regimes and so their respective palaeoceanographic and palaeoclimatological settings in two mound provinces, respectively the Belgica mound province and the Magellan mound province. Both provinces show at present time clear differences in the hydrodynamic environment. This study confirms that also during the past the oceanographic and sedimentological environment of both provinces differ clearly. Impacts of glacial-interglacial variations and locally derived ice rafting events (IRE), comparable with the North Atlantic Heinrich events (HE) have been recognized in both provinces. Moreover, the combination of X-ray imagery, magnetic susceptibility, gamma density and P-wave velocity makes it possible to estimate the coral con-
\end{abstract}

A. Foubert $(\bowtie) \cdot$ D. Van Rooij · J.-P. Henriet

Renard Centre of Marine Geology, Ghent University,

Krijgslaan 281 S8, 9000 Gent, Belgium

e-mail: Anneleen.Foubert@UGent.be

D. Blamart · D. Van Rooij

Laboratoire des Sciences du Climat et de l'Environnement/

IPSL, Laboratoire mixte CNRS/CEA/UVSQ,

Bâtiment 12, 4 avenue de la Terrasse,

91198 Gif-sur-Yvette, France tent and coral distribution in unopened cores localized on top of carbonate mounds. A comparison between on-mound and off-mound cores in both provinces allowed revealing some mechanisms of mound evolution and coral growth versus time.

Keywords X-ray imagery · Physical core logging · Carbonate mounds · Porcupine basin .

Palaeoceanography

\section{Introduction}

The Porcupine Seabight forms a deep embayment in the Atlantic shelf, off the southwestern coast of Ireland (Fig. 1). This region gained fame already at the end of the nineteenth century for its special deep-water habitats (Thomson 1873; Le Danois 1948). Hovland et al. (1994) were the first to publish seismic profiles picturing the mound structures of up to $200 \mathrm{~m}$ high and more than $1,500 \mathrm{~m}$ long. Very-high resolution seismic profiling has confirmed the presence of large seabed (carbonate) mounds (Henriet et al. 1998; De Mol et al. 2002; Huvenne et al. 2002). The mounds occur in three well-delineated provinces, featuring distinct morphologies. The Belgica mound province on the eastern flank is characterized by conical mounds asymmetrically buried along the eastern slope of the Seabight within a bathymetric interval of $500-1,000 \mathrm{~m}$ over a distance of $20 \mathrm{~km}$ (De Mol et al. 2002). In the north, the Magellan mound province features large numbers of small, buried mounds (Huvenne et al. 2003). South of them, complex mound structures at the seafloor are found in the Hovland mound province. De Mol et al. (2002) present a first general description of the mor- 
phology, seismic facies and sedimentology of the three mound provinces. They interpret the mounds as coral banks formed by a framework of cold-water corals and other macrobenthos, baffling sediments in an oceanographically dynamic environment. The mechanisms behind mound formation and mound growth are up to now only poorly understood. However it has been suggested that specific oceanographic conditions are an important factor controlling mound and cold-water coral growth (De Mol et al. 2002; Freiwald 2003).

This paper will focus on the integration of X-ray imagery and physical properties for the study of onmound and off-mound cores in Porcupine Seabight. Two main sites are targeted in this study, localized respectively in the Belgica mound province and the Magellan mound province. The cores and their physical properties will be evaluated in view of (1) past and present oceanographic and sedimentological differences between both provinces and their effect on mound growth and (2) the influence of the presence of cold-water corals on physical properties and X-ray imagery.

\section{Geological and oceanographic context}

\section{Geological setting}

The Porcupine Seabight may be visualized as an amphitheater-shaped embayment in the Atlantic Irish shelf and is enclosed by four shallow platforms: Porcupine Bank on the western side, Slyne Ridge in the north, the Irish Mainland Shelf in the east and Goban Spur in the south (Fig. 1). Only a relatively small opening towards the deeper, North-Atlantic basin is present in the southern part. All these barriers consist of metamorphic Precambrian and Paleozoic rocks. The underlying basinal structure is a Middle to Late Jurassic failed rift of the proto-North Atlantic (Croker and Shannon 1987; Naylor and Shannon 1982). During the overall Cenozoic post-rift period, which is mainly characterized by thermal subsidence, approximately $10 \mathrm{~km}$ of sediment has been deposited in the centre of the basin, which gradually onlap the basin margins (Croker and Klemperer 1989; Moore and Shannon 1992). Probably during Pliocene times, cold-water corals started settling in three different provinces in Porcupine Seabight (Henriet et al. 1998; De Mol et al. 2002; Huvenne et al. 2002; Van Rooij et al. 2003).

Few studies concern the quaternary sedimentation in the Porcupine Basin, although recent work indicates a multitude of sedimentary processes. In general, Rice et al. (1991) describe an overall pelagic to hemipelagic sedimentation. Sidescan sonar imagery

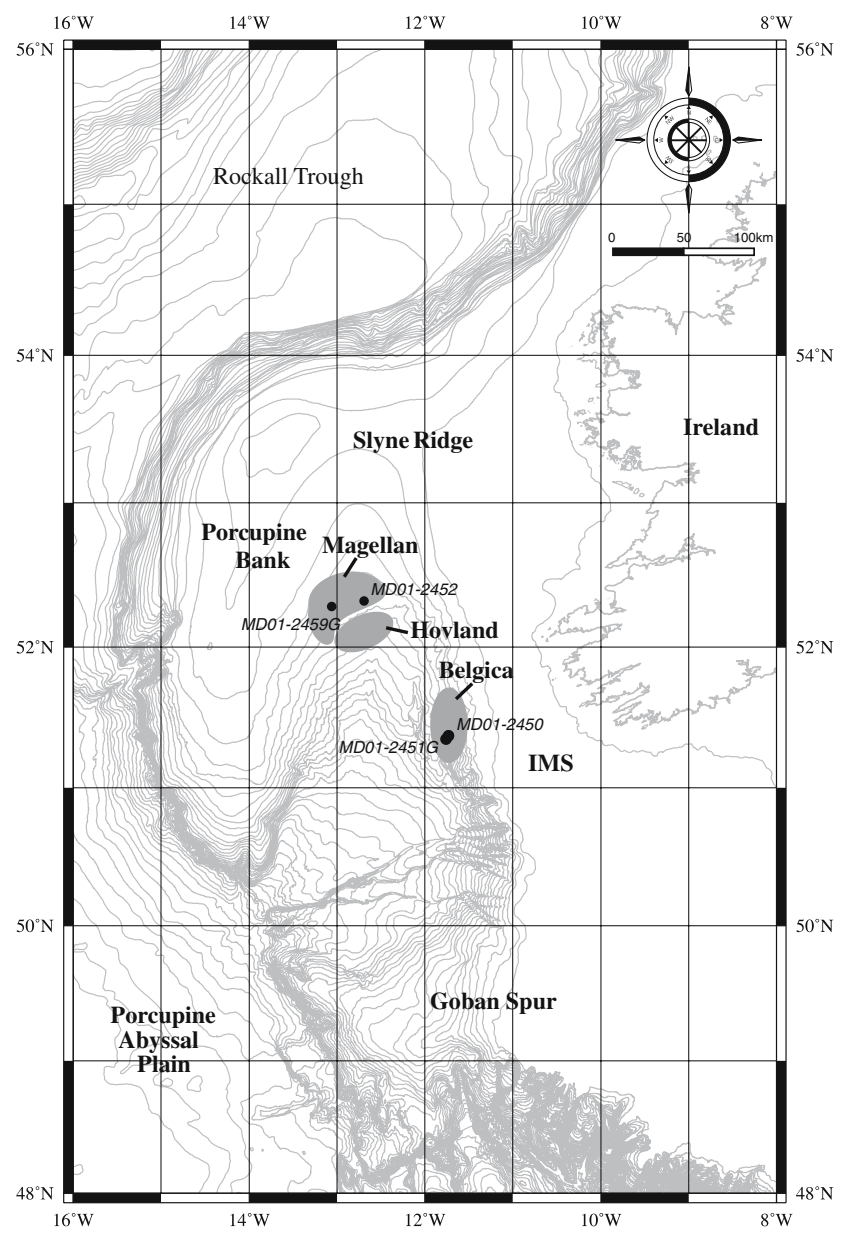

Fig. 1 Overview map of the Porcupine Seabight with main morphological features, localization of the mound provinces and localization of the cores. IMS Irish Mainland Shelf. Contour interval is $100 \mathrm{~m}$

shows clearly that the sedimentary environment in the Magellan-Hovland mound provinces in the northern Porcupine Seabight is much quieter at present times than in the Belgica mound region on the eastern flank of the basin, where gravel lags and coarser sediments are found together with patches of sorted sands, striations, barchan dunes and sediment waves (Huvenne et al. 2002, 2005; Wheeler et al. 2005). Van Rooij et al. (2003) present seismic evidence for the existence of two types of sediment drifts on the eastern flank of the Porcupine Seabight, an elongated and a confined drift whereby the uppermost sediment units are interpreted as phases in a slope parallel drift under changing oceanographic conditions.

A $26 \mathrm{~m}$ long core (MD99-2327) within this contourite drift sediments provides a record of possibly $100 \mathrm{ka}$ of sedimentation history (Van Rooij et al. 2006). It is suggested that during glacial times, a muddy 
contourite sedimentation environment dominates withsubtle variations in the currents vigour. In interglacial times, a similar lithofacies is found as on the present-day sea floor: a sandy foraminiferal ooze, which is interpreted as a sandy contourite, caused by the reinstallation of interglacial hydrographic conditions in which the Mediterranean outflow water (MOW) is an important factor. Moreover, the sedimentary record of the studied core has been largely influenced by the nearby presence of the British Irish Ice Sheet (BIIS). Locally derived ice rafting events (IRE) are described, which can be compared with the North Atlantic Heinrich events (HE) (Van Rooij et al. 2006).

\section{Hydrographic setting}

Water depths range from $250 \mathrm{~m}$ in the north to more than 3,000 $\mathrm{m}$ in the southwest at the mouth of the Seabight. The water mass structure has been revised by Hargreaves (1984), Rice et al. (1991) and White (2001). The upper layer $(<750 \mathrm{~m})$ consists of Eastern North Atlantic Water (ENAW). Between ca. 750 and 1,500 m a core of MOW can be found, characterized by a salinity maximum and oxygen minimum. Labrador seawater (LSW) is present between 1,500 and 1,750 m, underlain by Norwegian seawater (NSW). Modelling and current measurements suggest the existence of a general thermohaline northerly-flowing current along the eastern slope of Porcupine Seabight (Pingree and Le Cann 1989, 1990; White 2001; New et al. 2001). At the northern end of the Seabight currents are relatively weaker with some evidence of topographic steering of the mean flow cyclonically around the slope of the Porcupine Seabight (White 2001). Locally strong internal waves and tides (Rice et al. 1991; White 2006) are recognized on the eastern margin of Porcupine Seabight within the depth range of outcropping mounds in the Belgica mound province. The detailed hydrography of the Seabight is described by White (2006).

\section{Material and methods}

\section{Geophysical data}

High-resolution single-channel surface sparker seismic data has been acquired over the three mound provinces with the R/V Belgica during RCMG Porcupine expeditions from 1997 until 2001. The seismic signal was created with a SIG surface sparker source $(500 \mathrm{~J})$, resulting in a frequency between 200 and $3,000 \mathrm{~Hz}$. The obtained vertical resolution of this method is $0.5-1 \mathrm{~m}$. The acoustic penetration ranges from 400 to $800 \mathrm{~ms}$ two-way travel time (TWT). The data of all surveys were digitally recorded on an ELICS Delph 2-system with a sample rate of $4 \mathrm{kHz}$ and processed with Landmark PROMAX software on a SUN workstation. The data processing involved a Butterworth bandpass filter ( $250 \mathrm{~Hz}$ with a $24 \mathrm{db} /$ oct slope and $700 \mathrm{~Hz}$ with a $36 \mathrm{db} /$ oct slope), minimum phase spike deconvolution, automatic gain control using a mean of $250 \mathrm{~ms}$ and a true amplitude recovery. Each coring site is documented with at least two crossing seismic lines. Detailed multibeam bathymetry, covering the entire Belgica mound province, was obtained by means of a $15.5 \mathrm{kHz} \mathrm{Hy}-$ drosweep 2DS multibeam echosounder, during the AntXVII/4 campaign of the R/V Polarstern in June 2000 (Beyer et al. 2003). Bathymetric information, kindly provided by the Geological Survey of Ireland (GSI Dublin) was used to localize the cores in the Magellan mound area. Sidescan sonar imagery has been acquired during the TOBI survey covering the Magellan and Belgica mound provinces (RV Pelagia cruise) with a $30 \mathrm{kHz}$ sidescan sonar mounted on the TOBI vehicle (de Haas et al. 2002; Huvenne et al. 2005).

\section{Sedimentological data}

The cores available for this study were obtained with a Calypso piston corer for the off-mound cores (MD012450, MD01-2452) or a gravity corer for the on-mound cores (MD01-2451G and MD01-2459G) on board of the R/V Marion Dufresne during the MD123Geosciences campaign (September 2001), within the framework of the EC FP5 Geomound project (Table 1).

All cores were analysed with the GEOTEK Multi Sensor Core Logger at a resolution of $2 \mathrm{~cm}$, measuring magnetic susceptibility (Bartington loop sensor MS2B), GRAPE density ( $\mathrm{Cs}^{137}$ source with energies principally at $0.662 \mathrm{MeV}$ ) and $\mathrm{P}$-wave velocity (P-wave "piston" transducers) on whole round sections. The calypso cores were opened, described and photographed with a digital camera. The reflectance was measured with a Minolta colour spectrophotometer. The gravity cores were left unopened and were submitted to X-ray analyses with the SCOPIX X-ray equipment (DGO, Université Bordeaux I) to estimate the coral content and the coral distribution. SCOPIX uses classical X-ray equipment (X-ray source: $160 \mathrm{kV}$, $19 \mathrm{~mA}$ ), coupled with new radioscopy instrumentation (CCD camera $756 \times 581$ resolution), connected to a computer for data acquisition and processing (Migeon et al. 1999). All whole core sections (150 cm long) were cut in two representing sections of $75 \mathrm{~cm}$, in order to reduce weight of the chariot. The whole cores were put 
in the chariot and parts of $10 \mathrm{~cm}$ were $\mathrm{X}$-rayed and digitally processed and saved (Fig. 2). The X-ray images were then plotted in intensity grey scale logs. The density of a substance is the predominant factor determining X-ray attenuation, darker colours corresponds with denser material (Lofi and Weber 2001).

\section{Environmental setting}

The discussed cores are localized respectively in the Belgica mound province and in the Magellan mound province. In order to better understand the sedimentary processes recorded in the cores, a short review will be presented on the local environmental setting of these provinces.

In the Belgica mound province (Fig. 1), the Challenger mound was targeted (MD01-2450 and MD012451G) (Fig. 3a). The multibeam bathymetry reveals that this mound is part of a north-south aligned level of coral banks at depths of 500-1,000 m (Beyer et al. 2003; Van Rooij et al. 2003). Challenger mound is a typical conical, asymmetrical buried mound, with a more buried upslope side and a well exposed basinward side (Fig. 3b). Sidescan sonar imagery shows a rather high-backscatter facies of irregular texture in between the mounds and numerous bedforms indicative of strong bottom currents and active sediment transport (de Haas et al. 2002; Huvenne et al. 2005; Wheeler et al. 2005). A regional seismic stratigraphic framework of this mound province has been discussed by Van Rooij et al. (2003) who distinguished three units separated by two regional discontinuities (RD1$\mathrm{RD} 2$ ). A general overview of the stratigraphic framework in the neighborhood of the cores is presented in Fig. 3b, showing two of the described units, respectively unit 1 and unit 3 separated by the RD1. Unit 3 is characterized by subparallel, gently basinwards dipping reflectors. Further downslope and under the moundbase upslope migrating sigmoidal bodies are observed, interpreted by Van Rooij et al. (2003) as buried sediment waves, associated with sediment drifts. The recentmost unit 1 , characterized by continuous,

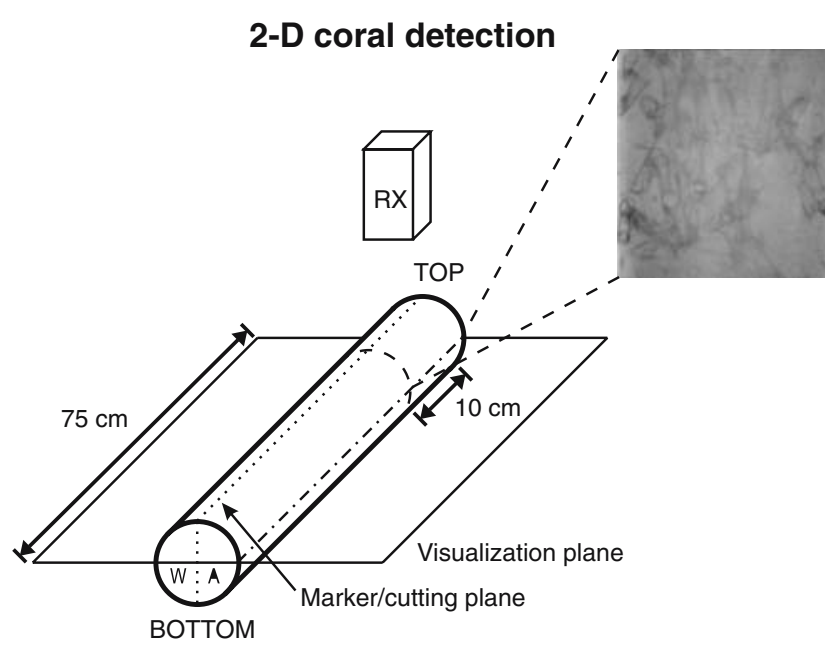

Fig. 2 Method of X-ray analyses for unopened cores containing coral fragments as used with the SCOPIX (DGO, U. Bordeaux I)

high-frequency reflectors, is deposited after a dramatic erosion event causing the RD1 discontinuity with a probable Late Pliocene age (Van Rooij et al. 2003). Core MD01-2450 is situated at the SW flank of Challenger mound, where intense currents can be expected. Gravity core MD01-2451G is situated on top of the mound and had the intention to penetrate as deep as possible into Challenger mound.

The second site is located within the Magellan mound province, more specific on mound Perseverance (MD01-2459G) and in the sediments above some buried Magellan mounds (MD01-2452) (Figs. 4a, 5a). A detailed study of this area has been performed by Huvenne et al. (2003, 2006). On the TOBI sidescan imagery the Magellan province appears as an area with a homogeneous acoustic facies of medium, although rather 'grainy' backscatter strength (Huvenne et al. 2005), which can be linked to bioturbated muddy or silty hemipelagic sediments (Kenyon et al. 1998). The seabed has a gentler slope and a more regular appearance, without erosion or sedimentation patterns, such as bedforms, as observed in the Belgica mound province. Most mounds are buried under a sediment drape but some mounds
Table 1 Localization and characterization of the studied cores MD01-2450, MD01-2451G, MD01-2452 and MD01-2459G

\begin{tabular}{llllll}
\hline Core & $\begin{array}{l}\text { Recovery } \\
(\mathrm{m})\end{array}$ & $\begin{array}{l}\text { Depth } \\
(\mathrm{m})\end{array}$ & Type & \multicolumn{2}{l}{ Coordinates } \\
\cline { 4 - 5 } & & & & Latitude & Longitude \\
\hline MD01-2450 & 11.97 & 944 & Calypso & $51^{\circ} 22^{\prime} 31.27^{\prime \prime}$ & $11^{\circ} 43^{\prime} 48.71^{\prime \prime}$ \\
MD01-2451G & 12.84 & 762 & Gravity & $51^{\circ} 22^{\prime} 47.99^{\prime \prime}$ & $11^{\circ} 43^{\prime} 03.45^{\prime \prime}$ \\
MD01-2452 & 18.43 & 617 & Calypso & $52^{\circ} 19^{\prime} 23.78^{\prime \prime}$ & $12^{\circ} 41^{\prime} 28.61^{\prime \prime}$ \\
MD01-2459G & 10.79 & 610 & Gravity & $52^{\circ} 18^{\prime} 00.60^{\prime \prime}$ & $13^{\circ} 02^{\prime} 51.00^{\prime \prime}$ \\
\hline
\end{tabular}




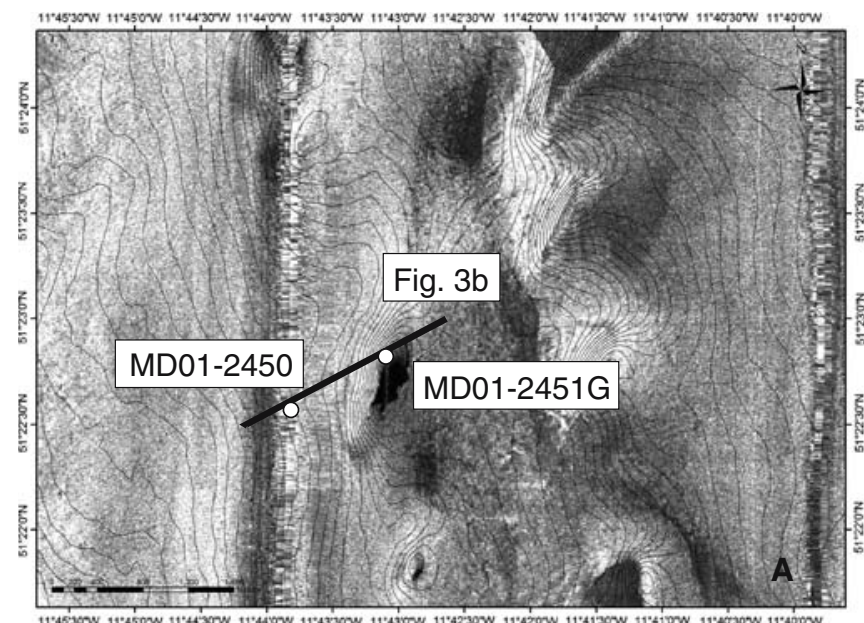

Fig. 3 Localization of cores MD01-2450 and MD01-2451G (Belgica mound province). a TOBI sidescan sonar imagery of Challenger mound and his surroundings (de Haas et al. 2002) and detailed multibeam bathymetry (Beyer et al. 2003). Contour

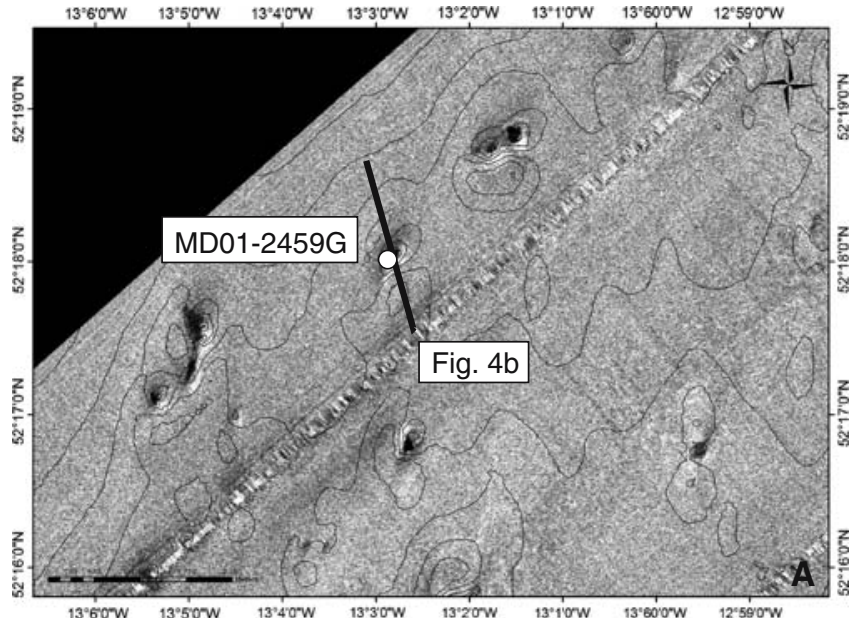

Fig. 4 Localization of core MD01-2459G (Magellan mound province). a TOBI sidescan sonar imagery of mound Perseverance and his surroundings (de Haas et al. 2002) and GSI

(like mound Perseverance) form clear features in the topography. Gravity core MD01-2459G (Fig. 4b) is situated on top of mound Perseverance, which is elevated about $50 \mathrm{~m}$ above the present-day seabed, and is elongated in a NNE/SSW direction. The fourth core (MD01-2452) is situated in the sediments over the buried Magellan mounds (Fig. 5b). These mounds are embedded in a unit of semi-parallel stratified reflections, sometimes abut abruptly against the mound flanks, and in other cases bent downwards creating a depression or a moat surrounding the mound (Huvenne et al. 2006).

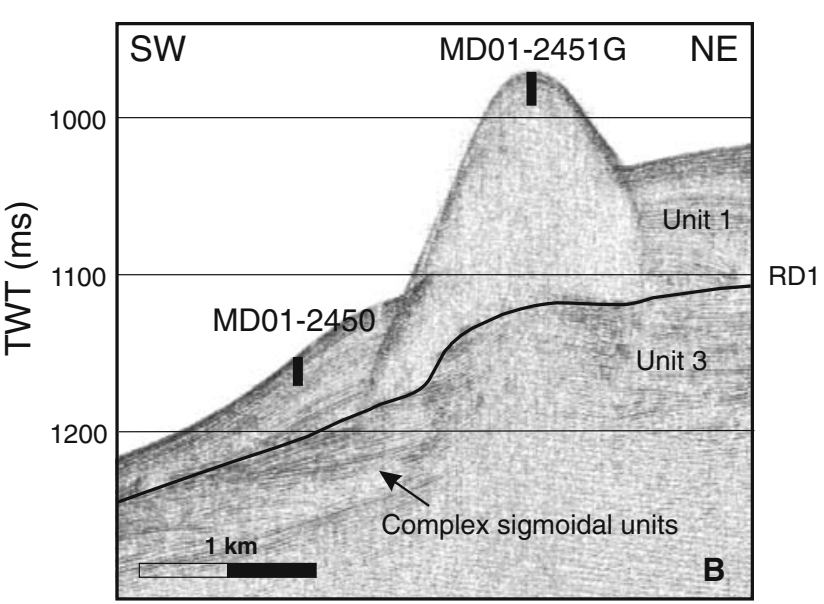

interval is set at $10 \mathrm{~m}$. b SW-NE orientated RCMG sparker profile with localization of the core sites MD01-2451G and MD01-2450 and seismic-stratigraphic features, as defined by Van Rooij et al. (2003)

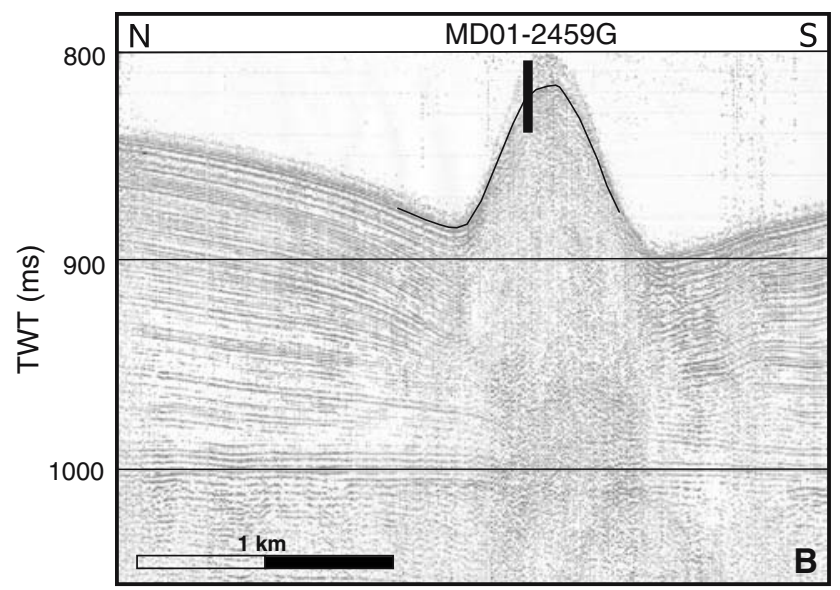

multibeam bathymetry. The contour interval is set at $10 \mathrm{~m}$. b NNW-SSE orientated RCMG sparker profile with localization of the core site

\section{Results}

\section{Off-mound cores}

The off-mound cores are studied in order to provide a tentative palaeoclimatic framework. Glacial-interglacial variations can be seen in the background variations of the magnetic susceptibility signals (Robinson et al. 1995; Grousset et al. 1993). Changes in magnetic susceptibility are due to changes in the concentration and the composition (grainsize and/or mineralogy) of the present magnetic minerals. These variations in Late- 

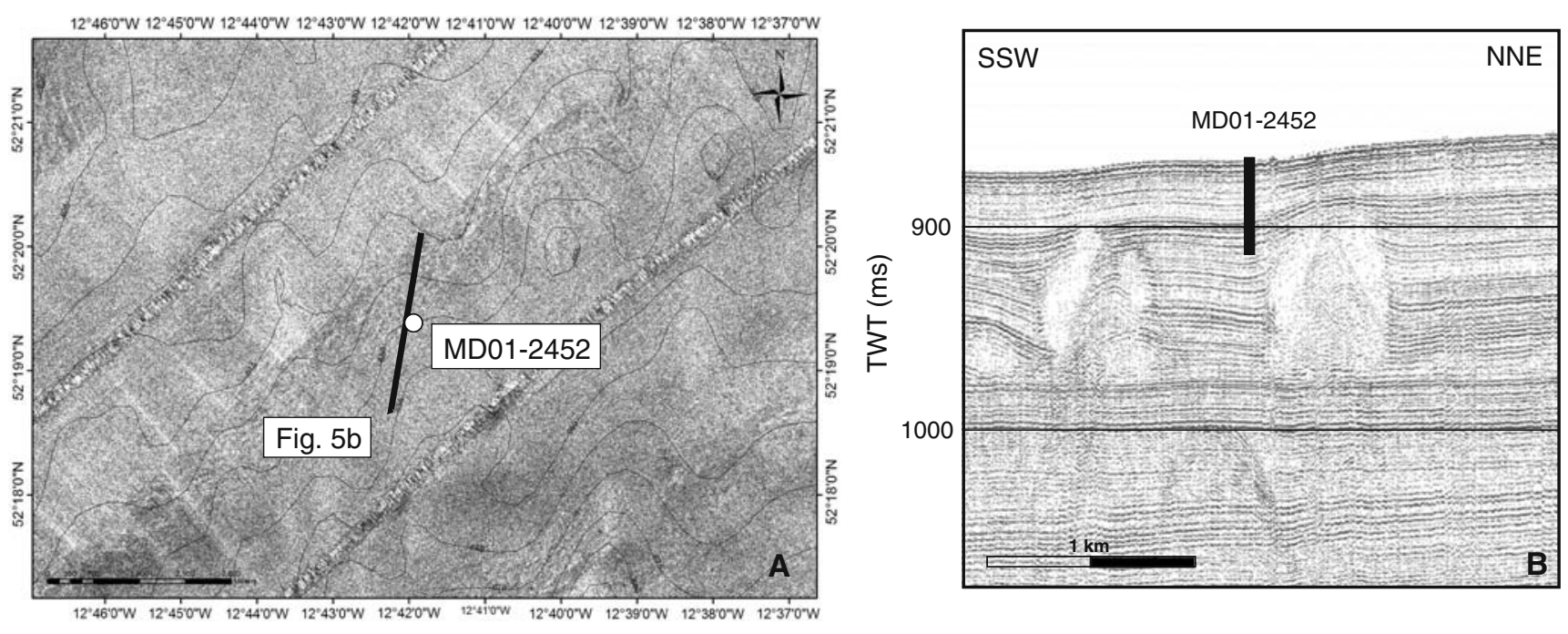

Fig. 5 Localization of core MD01-2452 (Magellan mound province). a TOBI sidescan sonar imagery of sediments above buried Magellan mounds (de Haas et al. 2002) and GSI multibeam

Cenozoic sediments of the NE Atlantic Ocean can be explained by changes in carbonate productivity and amount of ice rafted debris (IRD) driven by oceanographic variations triggered by climatic changes. Warmer periods have a lower susceptibility background signal, colder periods a higher. The individual maxima, with more than an order of magnitude difference compared to the background signals, can be explained by high-frequent IRE characterized by the deposition of sandy, magnetite-rich IRD (Robinson et al. 1995; Thouveny et al. 1994, 2000; Richter et al. 2001).

Gamma density and P-wave velocity reflect changes in the lithology and porosity, which could be interpreted in terms of changing oceanographic and palaeoclimatic conditions. Interglacial periods within the PSB seem to be characterized by coarser material due to enhanced currents (Van Rooij et al. 2003), whereas glacial periods are characterized by the deposition of finer material witnessing of quieter deposition environments. Individual IRE correspond to maxima in gamma density and P-wave velocity due to the abrupt increase of coarser material (IRD). However, the gamma density should be interpreted with caution because a slightly increase in the density by going downwards can be explained by compaction. Cortijo et al. (1995) have shown that the reflectance can be an estimation of the carbonate productivity and so a reflection of changing oceanographic conditions due to glacial-interglacial variations.

The descriptions of the susceptibility signals combined with the measured values of the gamma-density, $\mathrm{P}$-wave velocity and reflectance suggest a subdivision in different units and distinctive layers, which can be bathymetry. The contour interval is set at $10 \mathrm{~m}$. b SSW-NNE orientated RCMG sparker profile through core site

interpreted in terms of palaeoenvironmental and palaeoclimatic changes.

\section{MD01-2450: SW flank of Challenger mound (Belgica mound province)}

Core MD01-2450 can be divided in four units and six distinctive layers based on a comparison of the lithology with the different geophysical parameters (Fig. 6). A detailed description of the four units, respectively from the top to the base of the core, will be given in the next paragraphs to establish a tentative palaeoclimatic framework.

\section{Unit A $(0-210 \mathrm{~cm})$}

The upper part of the core $(0-210 \mathrm{~cm})$ consists of homogenous structureless olive gray silty clays with common to abundant nannofossils and few sulphide specks. The susceptibility increases slightly from the base to the top of the unit, while the gamma density decreases. The decrease in gamma density can be explained by a combination of the loosely packed uppermost sediments and a lack of sandy material, which is normally expected at the present-day seafloor (Foubert et al. 2005). Both, the lack of typical foraminiferal-rich sands and the tendency for higher susceptibilities and lower densities compared to the subsequent units, form evidences that the sediments from unit $\mathrm{A}$ are witnessing a colder period. The $\mathrm{P}$-wave velocity values are not trustable in unit $A$ due to a bad contact of the P-wave transducers with the cores during 
Fig. 6 Interpretation of core MD01-2450 based on magnetic susceptibility $(S I)$, gamma density $\left(\mathrm{g} \mathrm{cm}^{-3}\right)$, Pwave velocity $\left(\mathrm{m} \mathrm{s}^{-1}\right)$ and reflectance $\left(\mathrm{L}^{*}\right)$ in function of the depth. Light gray boxes correspond with IRE. Dark gray box indicates a turbidite. A tentative correlation with Marine Isotopic Stages (MIS) according to Martinson et al. (1987) is proposed

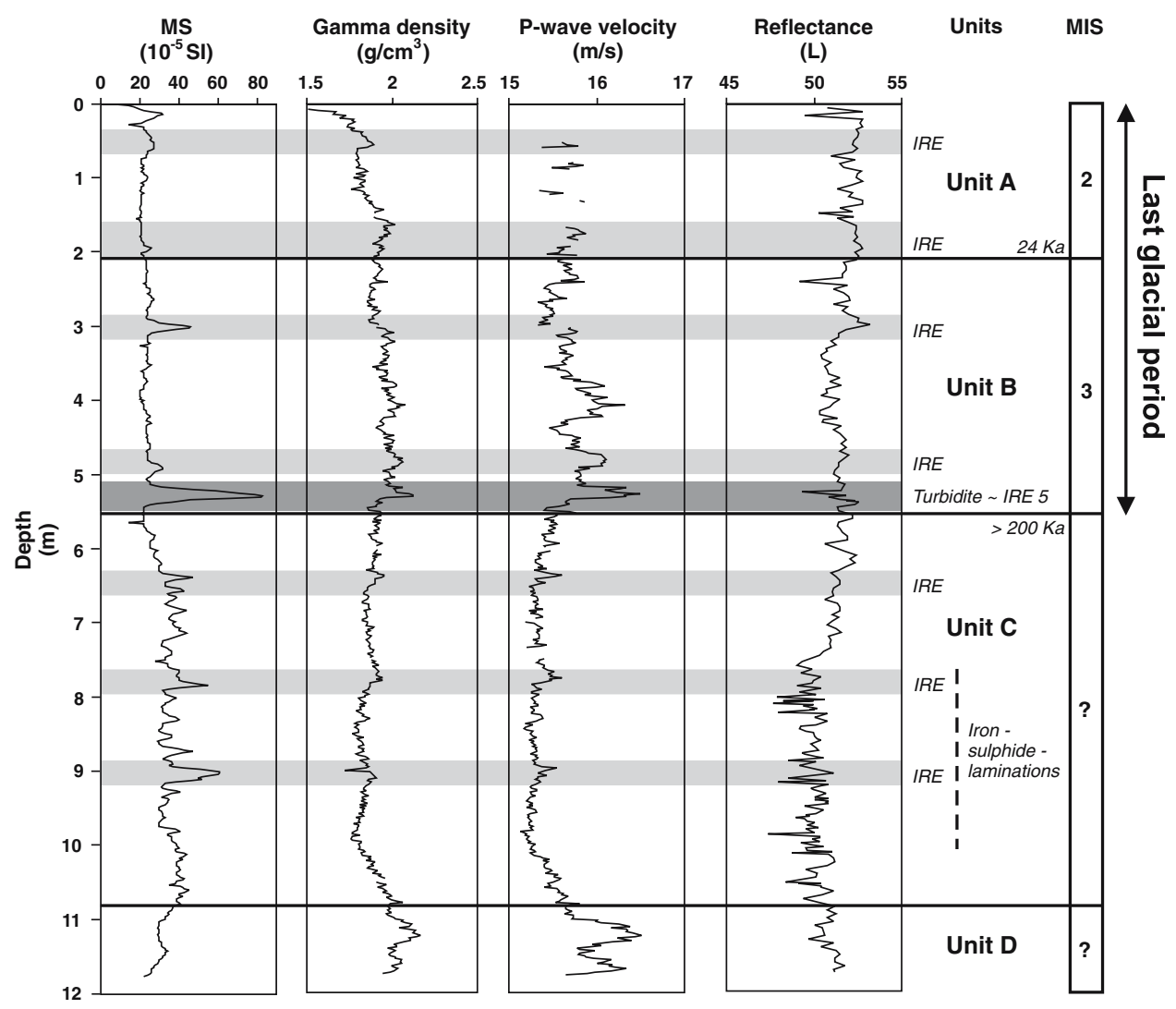

measuring. The maxima in gamma density and susceptibility around $50 \mathrm{~cm}$ indicate the presence of IRD, and so probably the imprint of an IRE. A second maximum in gamma density is observed around $175 \mathrm{~cm}$, followed by a relatively small peak in susceptibility around $195 \mathrm{~cm}$. The combined interpretation of both parameters suggests the presence of a second IRE between 170 and $200 \mathrm{~cm}$.

\section{Unit B $(210-540 \mathrm{~cm})$}

Generally, this part of the core consists of olive grayish bioturbated silty clays with common to abundant nannofossils and few sulphide specks. Fine to medium sandy intercalations and a few centimeter-scale silt layers are present in between the silty clays. The gamma density and P-wave velocity present higher and more fluctuated values in unit B due to the pockets and intercalations of sand- and silt-sized material. The higher abundance of coarser material can correspond to a slightly warmer period, taking into account the interpretations of Van Rooij et al. (2003).

All relevant parameters (magnetic susceptibility, gamma density, P-wave velocity and reflectance) correspond with maxima at depths around 300 and $485 \mathrm{~cm}$ which can be explained by the presence of IRD (visualized at $485 \mathrm{~cm}$ core depth by the presence of medium-sized dropstones) deposited during IRE. The second IRE in this unit features again a slightly offset in the density and P-wave velocity maxima (at $480 \mathrm{~cm}$ depth) from the maximum in magnetic susceptibility (at $490 \mathrm{~cm}$ depth).

An important change in lithology can be observed between 510 and $540 \mathrm{~cm}$ core depth. Visual observations suggest a coarsening downwards trend from $510 \mathrm{~cm}$ on to a gravely sand layer with an erosional basal contact at $535 \mathrm{~cm}$. At the same depth a distinctive peak is registered in the susceptibility, gamma density and P-wave velocity, while the reflectance corresponds with a minimum. Previous observations suggest the record of a mass event such as a turbidite. The presence of dropstones in the same interval suggests that probably a combination of an ice rafting event with a turbiditic event contributes towards the creation of the remarkable sedimentary record at these depths.

Unit C (540-1,080 cm)

Unit C (540-1,080 cm) is build up of silty clayey material, similar as in unit A, but typified by a high 
concentration of sulphide specks and sulphide concentrations turning into clear frequent semi-parallel sulphide-laminations $(\mathrm{FeS})$ between 750 and 1,050 cm. Each layer is approximately $1-2 \mathrm{~cm}$ in thickness and occurs with an average spacing of 1-2 $\mathrm{cm}$. The higher and more irregular susceptibility signals within this unit can be explained by the high concentration of iron sulphide concretions and laminations (Thompson and Oldfield 1986; Maher and Thompson 1999; Roberts 1995). Sulfate reduction-either occurring due to the oxidation of methane or the mineralization of other organic material-can lead to a pronounced overprinting or modification of the primary sediment composition by dissolution of minerals and precipitation of authigenic minerals (Berner 1970, 1984). Magnetic iron oxides (e.g. magnetite) dissolve under sulfate- and iron-reducing conditions and/or subsequent precipitation of authigenic minerals at different sediment levels may alter the magnetic signals and seriously influence the interpretation of the sedimentary magnetic record (Karlin and Levi 1983, 1985). The black colour of the laminations is expressed in the lower and irregular values of the reflectance at the corresponding depth intervals.

The general background signals of the gamma density and P-wave velocity are lower than in unit B. Combined with the silty clayey lithology as in unit A and a general higher background value of the magnetic susceptibility, this suggest the presence of a cold period.

Around respectively 640, 780 and $900 \mathrm{~cm}$ parallel peaks in magnetic susceptibility, P-wave velocity and gamma density are observed, which can be explained by the presence of IRD, deposited during IRE.

\section{Unit D (1,080-1,180 cm)}

From 1,080 to $1,180 \mathrm{~cm}$ (unit D) core MD01-2450 is composed of poorly sorted dark greyish silt with an intercalation of foram-rich fine sandy material between 1,095 and $1,130 \mathrm{~cm}$ comparable to the material as observed in boxcore samples and video-imagery from the present-day seafloor (Foubert et al. 2005). The magnetic susceptibility is low at the base of the core and slightly increase by going upwards. The gamma density and P-wave velocity are high compared to the previous described units. The similarities in lithology with the present-day situation (Holocene) as well as the rather low susceptibilities suggest the start of an interglacial period or the last culmination of a warm period before the onset of a colder period in unit $\mathrm{C}$.

\section{MD01-2452: Magellan mound province}

Core MD01-2452 shows clear variations in the background signals of the geophysical parameters, which suggest a tentative correlation with climatic changes (Fig. 7). Four units can be distinguished and different IRE, analogous to these observed in core MD01-2450.

\section{Unit A $(0-120 \mathrm{~cm})$}

Unit A $(0-120 \mathrm{~cm})$ consists of fine grayish brown sand to dark grayish brown silty clay with pockets of fine sand. The top of the unit $(0-20 \mathrm{~cm})$ is characterized by pure foraminifera-rich sand, characteristic for the sediments found at the present-day seafloor in the Magellan mound province (Huvenne et al. 2005) and thus can be interpreted as pure Holocene sand. The presence of more sandy material in the uppermost unit bears witness of a warmer period. The small maximum in susceptibility, gamma density and P-wave velocity at $78 \mathrm{~cm}$ core depth can indicate the presence of IRD in this uppermost part of the core, probably due to a last cold melt-water induced change in the ocean-atmosphere circulation during the early stages of deglaciation towards the warmer Holocene. This event is known as the Younger Dryas (YD) cooling.

\section{Unit B (120-1,030 cm)}

Unit B is composed of dark grayish brown silty clays with rare to abundant nannofossils. Few faint sulphide streaks can be observed throughout the bioturbated clays. The presence of silty clays combined with higher values of the susceptibility and lower values for reflectance in unit $\mathrm{B}$ compared to unit $\mathrm{A}$ can be explained by the presence of a record of sediments deposited during a colder period (the last glacial period). Between 540 and $878 \mathrm{~cm}$ slightly higher gamma densities (due to the presence of centimeter-scale layers of fine to medium sand from 812 to $870 \mathrm{~cm}$ ) and a higher reflectance (higher carbonate content) witnesses of a warmer period within this glacial. The individual maxima (respectively around 210, 480, 600, 700, 800, and $900 \mathrm{~cm}$ core depth) superimposed on the background signal of the susceptibility, gamma density and $\mathrm{P}$-wave velocity are the consequence of the presence of IRD, deposited during IRE. Most of these maxima show a multiple character (Fig. 7). Maxima in susceptibility and gamma density are preceded and/or followed by a smaller peak. Moreover, a small offset in the maximal susceptibility peak and the maximum in gamma density can be observed (e.g. IRE around $900 \mathrm{~cm}$ with a maximum in gamma density at $895 \mathrm{~cm}$ 
Fig. 7 Interpretation of core MD01-2452 based on magnetic susceptibility $(S I)$, gamma density $\left(\mathrm{g} \mathrm{cm}^{-3}\right), \mathrm{P}$ wave velocity $\left(\mathrm{m} \mathrm{s}^{-1}\right)$ and reflectance $\left(\mathrm{L}^{*}\right)$ in function of the depth. Grey boxes correspond with IRE. A tentative correlation with Marine Isotopic Stages (MIS) according to Martinson et al. (1987) is proposed

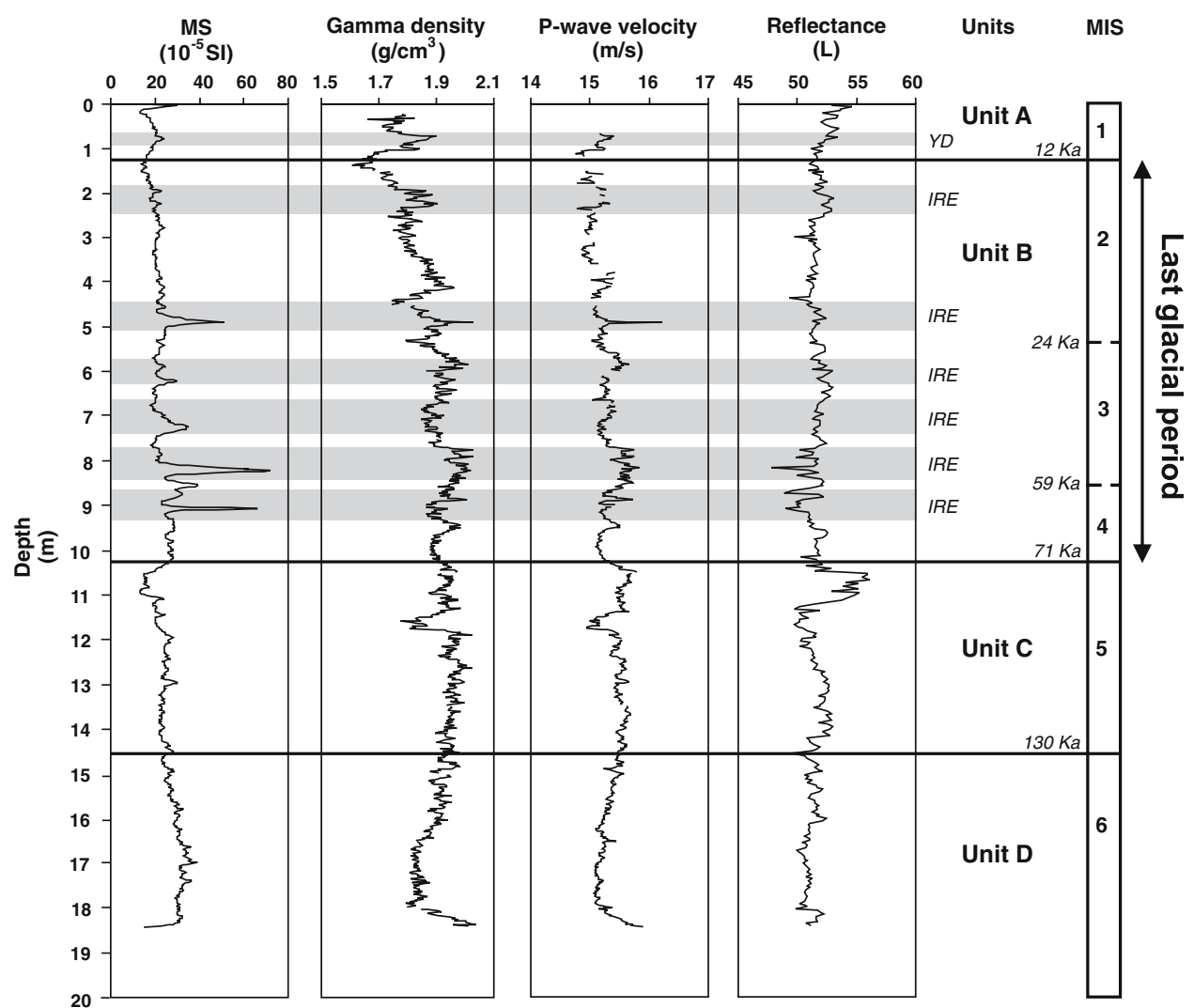

core depth and a maximum in susceptibility at $905 \mathrm{~cm}$ core depth). Such a multiple character and offset was also characteristic but less pronounced for the observed IRE in core MD01-2450.

\section{Unit C $(1,030-1,450 \mathrm{~cm})$}

From 1,030 to $1,140 \mathrm{~cm}$ unit $\mathrm{C}$ presents light brownish gray fine to medium sized sands gradually going over between 1,140 and $1,450 \mathrm{~cm}$ in dark grayish brown bioturbated clays with faint sulphide streaks. The abrupt decrease in magnetic susceptibility and increase in reflectance are probably due to the increase in carbonate content triggered by the culmination of a warm period between 1,030 and $1,140 \mathrm{~cm}$.

\section{Unit D $(1,450-1,843 \mathrm{~cm})$}

Unit $\mathrm{D}(1,450-1,843 \mathrm{~cm})$ is characterized by the typical dark grayish brown silty bioturbated clays with few faint sulphide streaks. Between 1,600 and 1,800 cm $\mathrm{mm}$-scale silty laminae are recognized within the silty clay going over in clayey silt with scattered pockets of coarse silt at the bottom of the core. This unit is characterized by higher susceptibility values and lower density, P-wave velocity and reflectance values compared to unit $\mathrm{C}$, evidencing of a colder period.

\section{On-mound cores}

The main information about the on-mound cores is interpreted from a combination of the physical properties data with the X-ray imagery. X-ray imagery allowed the identification of dead cold-water coral fragments and an estimation of the density of these fragments throughout the cores. Different "radiofacies" were observed, distinguished by the coral content (Fig. 8): a facies with no corals but only sediment (Fig. 8a), a combined facies consisting of small coral and bioclastic fragments (debris) embedded in a matrix of silty sediments (Fig. 8b) and a facies with large coral chunks filled up by sediments (sediment filled coral framework) (Fig. 8c). In both last defined facies the coral skeletons are darker than the surrounding sediments, which mean that the coral chunks are denser than the sediments. A fourth facies is identified that seems to be on first sight homogenous. A closer look learns that this facies is characterized by coral fragments figured on the X-ray images with a lighter colour than the surrounding sediments. So, the corals seem to be less dense than the surrounding sediment. This facies is interpreted as an altered coral-rich facies whereby corals are completely dissolved leaving skeleton footprints and carbonate-rich sediments behind. The interpretation of the X-ray images from both 


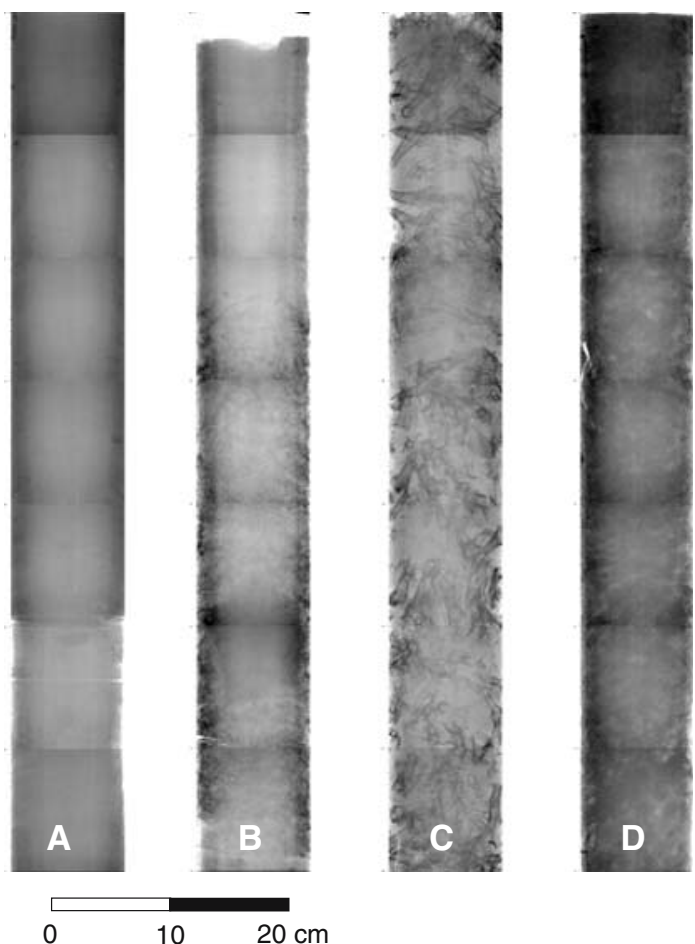

Fig. 8 Four different "radiofacies", based on the coral content (X-ray imagery); darker values represent denser material: a facies with no corals but only sediment, b a combined facies consisting of small coral and bioclastic fragments (debris) embedded in a matrix of silty sediments, c facies with large coral chunks filled up by sediments (sediment filled coral framework), d facies with altered or dissolved coral fragments

studied on-mound cores are schematized on Figs. 9 and 10. Magnetic susceptibility and gamma density can be correlated with the information extracted from the Xray images. Presented below is an overview and description of the alternating coral-rich, coral-poor and sediment-rich units and layers as observed on the $\mathrm{X}$ ray imagery and their correlation with the geophysical properties for respectively core MD01-2451G (top of Challenger mound) and core MD01-2459G (top of mound Perseverance).

\section{MD01-2451G: top of Challenger mound (Belgica mound province)}

Based on the geophysical properties and the X-ray imagery, generally two distinctive units can be recognized in core MD01-2451G (Fig. 9).

Unit A $(0-400 \mathrm{~cm})$

The magnetic susceptibility above $400 \mathrm{~cm}$ shows relatively high values in comparison to the subsequent unit (400-1,280 cm) (Fig. 9). The upper $400 \mathrm{~cm}$ of core
MD01-2451G is characterized by a highfrequent alternation of three distinctive coral-rich layers and three layers with homogeneous to bioturbated or laminated sediments (Fig. 9). The top of the core $(0-40 \mathrm{~cm})$ is composed of small coral rubble debris and broken bioclastic fragments, corresponding with a declining susceptibility pattern towards the top.

Between 40 and $219 \mathrm{~cm}$ bioturbated sediments are present with some apparent dropstones from 60 to $70 \mathrm{~cm}$ (Fig. 9). The whole layer corresponds to elevated magnetic susceptibility values. The dropstone interval $(60-70 \mathrm{~cm})$ can be correlated with a remarkably peak in magnetic susceptibility and gamma density at the same depth level, suggesting an ice rafted origin. The transition from this layer to the uppermost zone rich in small coral rubble fragments is rather gradual. In contrary a sharp boundary is noticed between the first sediment layer and the second layer, from 219 to $270 \mathrm{~cm}$, composed of coral rubble and fragmented bioclastic material. A plateau-shaped minimum in the magnetic susceptibility record is recognized at the same depth interval.

From 270 to $323 \mathrm{~cm}$ the core is again composed of highly bioturbated sediments, correlating with high magnetic susceptibilities. As observed in the first sedimentary layer, the transition to the coral-rich layer above is gradual, while the boundary with the next coral-rich layer below is sharp.

The third layer composed of coral rubble debris and small bioclastic fragments interfering with sediment occur from 323 to $375 \mathrm{~cm}$. A decrease in magnetic susceptibility is noted. However, a small peak in susceptibility and gamma density is observed from 350 to $356 \mathrm{~cm}$ and can be correlated with the presence of a big dropstone observed on the X-ray imagery. The observed dropstones represent partly the transition zone to a finely laminated sediment layer from $375 \mathrm{~cm}$ until the sharp base of unit A $(400 \mathrm{~cm})$ and form the fingerprints of an IRE (Fig. 9). The third sediment layer can be observed at the same depth levels in the geophysical parameters by elevated magnetic susceptibilities. So three cycles from the bottom to the top can be recognized in unit $\mathrm{A}$; one cycle consisting of bioturbated or laminated sediments going gradually over in a coral-rich layer and characterized at the top by a sharp contact which corresponds with the onset of the next cycle (Fig. 9).

Unit B (400-1,280 cm)

The lower part of the core $(400-1,280 \mathrm{~cm})$ is nearly completely composed of a sediment filled coral framework with a high concentration of large coral 
Fig. 9 X-ray $\log$ for core MD01-2451G (top Challenger mound) in comparison with the magnetic susceptibility $(S I)$ and gamma density $\left(\mathrm{g} \mathrm{cm}^{-3}\right)$. Insets display detailed features of dropstones (indicated with arrows) and fine laminated sediments going abrupt over in a coral-rich layer

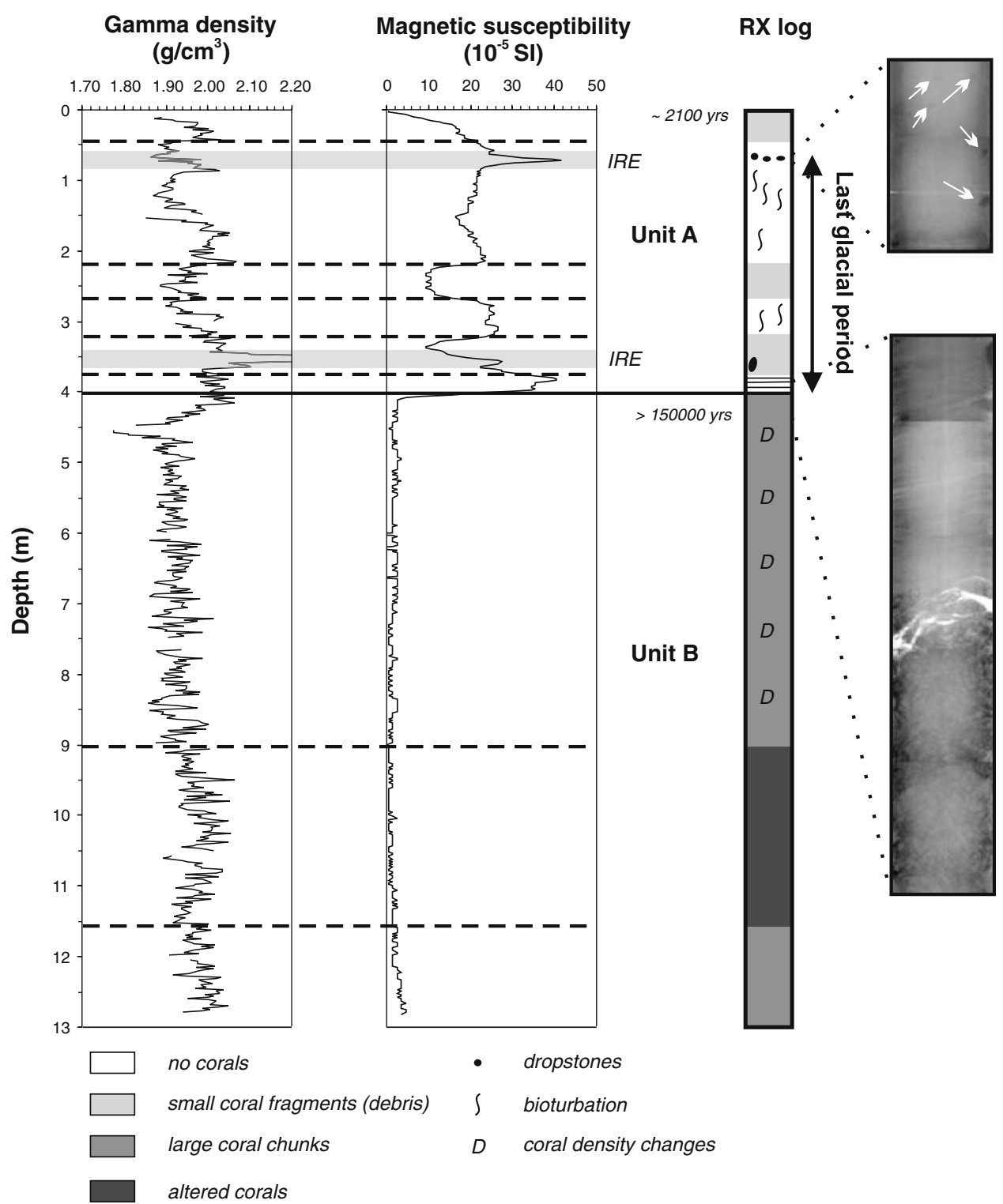

chunks changing in density throughout the unit. The shape and size of the imaged fragments at some intervals allowed identification of the coral species (Fig. 9), showing that the dominant coral species is represented by Lophelia pertusa. Extremely low values for the magnetic susceptibility are recorded in this coral-rich part of the core. The gamma density is more continue compared to unit A. From $900 \mathrm{~cm}$ onwards, the gamma density increases to slightly higher values, with maxima around $1,025 \mathrm{~cm}$ to decrease again until $1,150 \mathrm{~cm}$. A detailed look to the imaged coral fragments learns that in this small interval the walls of the coral fragments are thinner. So, dissolution of the fragments can be responsible for the observed higher gamma density, generating denser carbonate-rich background sediments and leaving soft and dissolved coral fragments behind. In the same interval the magnetic susceptibilities, still reaching values up to $3 \mathrm{SI}$ above $900 \mathrm{~cm}$, fall completely back to $0 \mathrm{SI}$ and even negative values are recorded. This can be explained by the presence of a higher amount of diamagnetic carbonate-rich minerals in the background sediments, which support the hypothesis of dissolution.

\section{MD01-2459G: top of mound Perseverance (Magellan mound province)}

The combination of physical properties and X-ray imagery allowed the identification of two units in core MD01-2459G (Fig. 10). 
Fig. 10 X-ray log for core MD01-2459G (top mound Perseverance) in comparison with the magnetic susceptibility $(S I)$ and gamma density $\left(\mathrm{g} \mathrm{cm}^{-3}\right)$

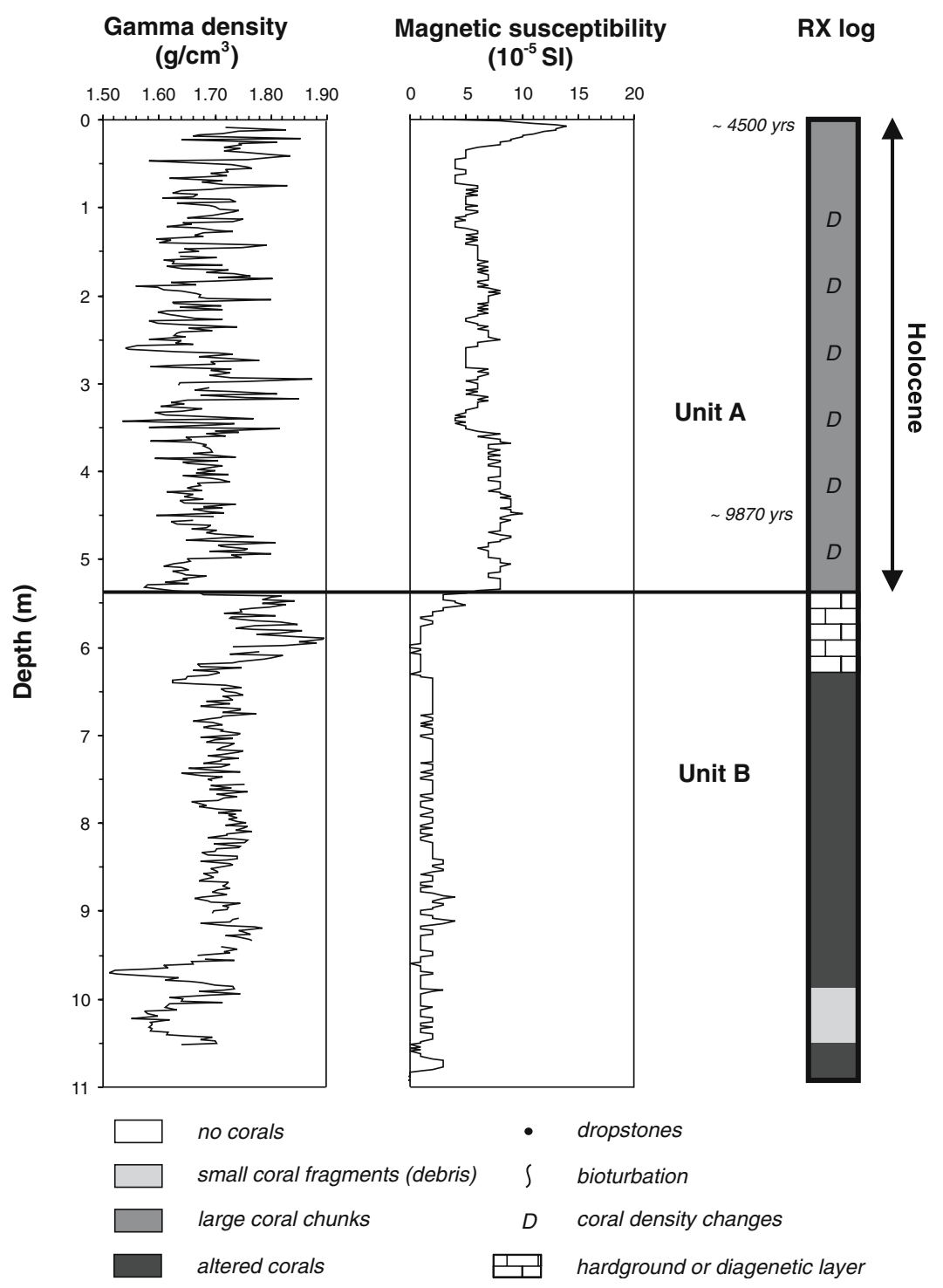

Unit A $(0-535 \mathrm{~cm})$

The uppermost part of the core, up to $535 \mathrm{~cm}$ is full of big coral chunks alternating in density (Fig. 10). The gamma density is highly variable due to the changing coral densities. The magnetic susceptibilities are rather low with values averaging around 5 SI.

Unit B $(535-1,079 \mathrm{~cm})$

In the lowermost part of the core $(535-1,079 \mathrm{~cm})$ corals cannot be clearly recognized on the X-ray images, except for a small interval between 985 and $1,050 \mathrm{~cm}$ characterized by small coral fragments. The
$\mathrm{X}$-ray images in this unit show a typical coral-altered facies. The magnetic susceptibility records extremely low values which can be explained by the presence of carbonate-rich sediments characterized by the presence of diamagnetic carbonate-minerals resulting in extremely low susceptibility values (at certain depths even turning into negative values). Gamma density changes are less pronounced in this lower part of the core, probably due to the creation of a more homogeneous facies rich in carbonate. Remarkable is the very high density from 535 to $600 \mathrm{~cm}$ corresponding with extremely high X-ray intensities, which can be interpreted as a possible hardground or a diagenetic layer. 


\section{Discussion}

Off-mound cores: carriers of palaeoenvironmental changes

Based on the known correlation of the geophysical parameters with the isotopic record and AMS $\mathrm{C}^{14}$-dates of a $26 \mathrm{~m}$ long piston core (MD99-2327) localized in the drift sediments upslope of Challenger mound, the different units recognized in the off-mound cores can be tentatively correlated with the marine isotopic stages (MIS) defined by Martinson et al. (1987) and recognized as such on core MD99-2327 by Van Rooij et al. (2006).

Unit A recognized as such in core MD01-2450 and evidencing of a colder period can be linked to MIS 2, while Unit B showing characteristics in the susceptibility, density and reflectance records of a warmer period, can be correlated with MIS 3 (Fig. 6). So, the whole upper part of the core evidences of the middle and the end of the last glacial period, whereby MIS 2 corresponds with the last glacial maximum. The lack of typical foraminifera-rich sands at the top suggests that the core does not contain typical Holocene sediments. This can be due to the piston coring method were the upper sandy sediments are blown away during sampling (Skinner and McCave 2003). Alternatively, the location of the core site in an area with active hydrodynamics may also suggest that most of the Holocene sediments could have been eroded in the recent past by vigorous bottom currents. Nowadays, the presence of enhanced currents in the Belgica mound province is highly dependant on the interaction of ENAW and MOW responsible for the creation of internal tides and waves (De Mol et al. 2002; White 2001, 2006). The input of Mediterranean Outflow Water may have played a very important role in earlier interglacial or warmer periods too (Schonfeld and Zahn 2000; Van Rooij et al. 2006). The warmer MIS 3 $(\sim$ unit $\mathrm{B})$ is characterized by the presence of a turbidite sequence and the local presence of coarser parts in the core, evidencing of a very dynamic and unstable deposition environment during this time. The lower part of the core, described as unit D, was characterized by the intercalation of sandy foram-rich material, typical found at the sea-floor during recent times and so witnessing of a warmer period similar to the present-day situation. Schonfeld and Zahn (2000) showed that the outflow of MOW was restricted to the Gulf of Cadiz during glacial times and did not penetrate further in the Atlantic Ocean, so the conditions for enhanced currents could not be reached, resulting in the deposition of more continuous records of finer material. The high energy associated with the deposition of a turbidite, as observed in MIS 3, can result in destruction of earlier deposited layers by subsequent turbidity currents creating a sharp erosional contact. It is not known how much material is removed during the observed turbiditic event but preliminary biostratigraphic investigations learn that the material below the erosional contact, corresponding with unit $\mathrm{C}$, must be older than 200 ka (D. Hebbeln, personal communication). These sediments bear evidences of a colder period.

Oxygen isotopic measurements performed on both benthic (mainly Cibicides kullenbergi) and planktonic foraminifera (N. pachyderma s.) and accelerator mass spectrometry (AMS) $\mathrm{C}^{14}$ dates (A. Jurkiw et al., in preparation) confirm the proposed tentative palaeoclimatic framework of core MD01-2450 and so the potential of geophysical parameters to facilitate palaeoenvironmental interpretations in the studied area.

The geophysical records of core MD01-2452 carry significant indications of glacial-interglacial variations (Fig. 7). The upper part of the core (unit A) is interpreted as pure Holocene sand and can be correlated with MIS 1. The observations of imprints characterizing a colder period in unit $\mathrm{B}$, can be linked with the last glacial period before the onset of the present Holocene, and so with MIS 2, 3 and 4 (Fig. 7). Unit $\mathrm{C}$ is characterized by the intercalation of a sandy layer but most of the unit is composed of silty clays. However, the records of the reflectance and magnetic susceptibility evidence of a warmer period which can be correlated with MIS 5. The last unit $\mathrm{D}$, witnessing of colder records can be again linked with a glacial period, i.e. MIS 6 . This last unit corresponds with the upper part of the seismic facies that buried most of the Magellan mounds. So, it is assumed that most of these mounds are buried during the glacial period corresponding with MIS 6 . Recent research (Huvenne et al. 2002, 2003) shows that the Magellan mound province bears witness of a hydrodynamically more stable environment than the Belgica mound province. It has to be mentioned that indeed no distinctive turbiditic sequences are recognized in the core record. Here, the climatic variations are not disturbed by mass-wasting processes from the shelf and the impact of bottom currents is not that intense as in the Belgica mound province. The impact of MOW in the northern part of the basin is less vigour than on the eastern margin of PSB. The proposed tentative palaeoclimatic framework is 
confirmed by biostratigraphic research on coccoliths (Thierens 2005).

In both cores clear IRE are recognized in the last glacial period. Frequent ice-rafting episodes are well known in the north-east Atlantic Ocean, called Heinrich events (Broecker et al. 1992). Heinrich layers were deposited when melting icebergs unloaded their debris en masse in the North Atlantic Ocean. The icebergs were released at the culmination of Dansgaard-Oeschger events, within the last glacial period (Bond et al. 1992). In the north-east Atlantic Ocean, in between $45^{\circ}$ and $53^{\circ} \mathrm{N}$ (= Ruddiman belt (Ruddiman 1977)), these Heinrich layers are associated with a strong magnetic susceptibility signal, due to a higher fraction of IRD containing multidomain, ferrimagnetic material (magnetite) and a smaller amount of detrital carbonate and quartz (Robinson et al. 1995; Grousset et al. 1993). However, the maxima in magnetic susceptibility values, correlating with the different IRE were not that pronounced in core MD01-2450 as in core MD01-2452. Core MD992327, located more upslope, also illustrates several IRE, characterized by a low magnetic susceptibility (Van Rooij et al. 2006; Richter et al. 2001). Probably the mass-wasting processes from the shelf and bottom currents have a great impact on the sedimentation in this part of the basin and could blur the impact of IRE. Another important factor is the origin of the IRD deposited during these IRE. Broecker et al. (1992) mentioned that the IRD, deposited during the $\mathrm{HE}$ in the north-east Atlantic Ocean, was mainly derived from the Precambrian gneisses of the Canadian shield with the Laurentide and Greenland ice sheets as the sole source of these events. Glacigenic detritus from these sources often contains primary, unaltered ferrimagnetic (magnetite) minerals (Thompson and Oldfield 1986). However, more recent work has provided evidence that European ice sheets also contribute to the story (Snoeckx et al. 1999; Grousset et al. 2000, 2001). Moreover, the described IRE in Porcupine Seabight are influenced by the proximity of the BIIS (Van Rooij et al. 2006). Icerafted material derived from the European continental margin contains detrital Campanian Upper Chalk, derived from bedrock sources eroded on the Celtic shelf by the BIIS (Scourse et al. 2000) and can thus be responsible for the less pronounced signals in the magnetic susceptibility. The pattern described from cores MD99-2327 (Van Rooij et al. 2006), MD01-2450 and MD01-2452 suggests a NW-ward increasing magnetic susceptibility, indicating the products of the Laurentide icebergs were losing intensity towards the Irish mainland or BIIS IRD diluted them.
Remarkable is the observation of the multiple character of the IRE in both cores. Recent isotopic research revealed that Heinrich events could be characterized by three-step internal structures (Grousset et al. 2000, 2001; Snoeckx et al. 1999). During the first step, IRD derived from the European ice sheets are released into the North Atlantic Ocean, displaying a so-called "precursor event". A second step, which may occur 1.0-1.5 ka after the start of the precursor event, is represented by a major input of Laurentide derived IRD. Finally during a last step, IRD from the European ice sheets are accumulated. Scourse et al. (2000) observed the same for Heinrich Layer 2 in two cores on the European Goban Spur-Porcupine continental margin, with a first deposition of chalk grains, derived from the BIIS and followed by the deposition of both British and Canadian derived IRD. Scourse et al. (2000) explains this by a more rapid response of the smaller British ice sheet on the external climatic forcing of Heinrich events. Only the real Laurentide events, and not the precursor events which contains more chalk-rich material, contains ferrimagnetic-rich IRD and are thus clearly visible in the susceptibility. This can explain the offset between peaks in the records of magnetic susceptibility and gamma density and the occurrence of a smaller peak in susceptibility before the actual maximum, whereby the first peak represents IRD from the BIIS, whereas the second peak in susceptibility corresponds with Canadian derived IRD.

On mound cores: revealing mechanisms of coral growth?

The first aim of the X-ray imagery was to describe the content of the coral cores, realized by the observation and interpretation of four different radio-facies (Fig. 8). A comparison of the X-ray logs with the susceptibility revealed a coherent correlation. The presence of cold-water coral fragments decreases the magnetic susceptibility significantly due to the aragonitic structure of the corals. However in most of the units the magnetic susceptibility does not reach negative values, probably due to the presence of siliciclastic material between the corals containing ferrimagnetic minerals. A uniform correlation between the gammadensity and the coral-density is not observed. However, the presence of sediment filled coral framework is responsible for a more discontinuous record of the gamma density, caused by the changing densities of coral fragments throughout the core. Another observed process, affecting the 
geophysical parameters is dissolution of the coral fragments and precipitation of $\mathrm{CaCO}_{3}$-rich background sediments. A process leading to such coral alteration could be the effect of organic matter-oxidation, affecting the saturation state of aragonite. The aragonite saturation state initially drops below 1 but becomes oversaturated during sulfate reduction. The $\mathrm{C}: \mathrm{N}$ ratio of the organic matter affects the degree of oversaturation, with $\mathrm{N}$-poor organic material resulting in a system more corrosive to aragonite, resulting in dissolution. Precipitation of sulfides as FeS strongly affects the aragonite saturation state, and systems with much $\mathrm{FeS}$ formation will have a stronger tendency to become oversaturated with respect to aragonite, resulting in carbonate precipitation. A pattern of initial carbonate dissolution followed by carbonate precipitation as a function of the extent of sulfate reduction can occur within reefs in a manner similar to that described for sediments (Tribble 1993). Throughout this process the interstitial waters maintain close to equilibrium compositions with aragonite. This buffers the $\mathrm{pH}$ of the waters. Because interstitial water in the reef has a short residence time, the observed equilibration suggests rapid kinetics. However, the effects of coral alteration have to be further investigated in detail. Anyway, this process leads to the production of $\mathrm{CaCO}_{3}$-rich background sediments, which alter the susceptibility and gamma density signals.

Based on the interpretation of the X-ray imagery and the geophysical parameters, glacial-interglacial changes could also be observed in both on-mound cores. U/Th dating on coral fragments cores helped in defining a palaeoclimatic framework (D. Blamart, personal communication, Frank et al. 2005) (Figs. 9, 10) and postulating some mechanisms of mound growth in respectively the Belgica mound province and the Magellan mound province.

The top of core MD01-2451G on mound Challenger yielded an age of 2,018 \pm 670 years calibrated BP (Frank et al. 2005). So, the uppermost layer of unit A can be interpreted as Holocene. The date for the top of the core suggests that the uppermost layer of mound Challenger is apparently missing, which can be explained by strong bottom currents eroding the uppermost sediments or preventing sediment deposition. Video surveying with the ROV Victor on board of R/V Polarstern in 2003 shows that the entire coral assemblage over Challenger mound is composed of dead coral rubble (Foubert et al. 2005). So, Challenger mound can be interpreted as a dead mound with no active coral growth during present times. It can be assumed that coral growth stopped completely around
2,000 years ago. Unit A is characterized by three cycles composed of alternating coral-rich and sediment-rich layers. The presence of dropstones (60-70, 350$356 \mathrm{~cm}$ ), witnessing of IRE, in between these cycles are typical glacial characteristics. Unit A can be mainly interpreted as the last glacial period going over into the Holocene at the top. The last glacial period within this region is known as one with high sedimentation rates and multiple IRE, as observed in core MD01-2450 and confirmed by Van Rooij et al. (2006).

The coral-rich unit B confirm that optimal conditions for the growth of cold-water corals were dominating in this part of the basin before the onset of the last glacial period. U/Th dating learns that most the coral fragments in this unit $\mathrm{B}$ are older than 150 ka calibrated BP (Frank et al. 2005). The sharp contact between unit $\mathrm{A}$ and unit $\mathrm{B}$, learns that some material could have been eroded. The fine laminations observed in the sedimentary layer draped over the coral-rich unit $\mathrm{B}$ can be connected to a high meltwater influx or turbid plumes (Auffret et al. 2002). Indeed, the impact of turbidites is also recorded in the off-mound core at the flank of the mound (MD01-2450). During such abrupt events turbidity currents can erode first most of the live deep-water corals and bury them in a next step, causing the horizontally laminated sediments. The high sedimentation rates during the last glacial period made it too difficult for the cold-water corals to keep their polyps sediment-free. However, the observation of three cycles evidences that some of the cold-water corals survived and succeeded to growth further. An interplay between siliciclastic sedimentation and coldwater coral growth took place whereby in some periods sedimentation gain on coral- and mound growth, while in the next stage cold-water coral growth takes again the overhand. However no healthy recovery of cold-water coral growth could be reached anymore.

The upper level full of corals in core MD01-2459G on mound Perseverance shows that this mound was (still) active during times that Mound Challenger was already in a stage of retirement. Ages of Lophelia corals range from 4,500 years at the core top to 9,780 years at 4,5 $\mathrm{m}$ core depth, indicating a Holocene growth episode for unit A. ROV video surveying showed that actively live corals are only found at the topmost part of mound Perseverance (Huvenne et al. 2005). The slightly offset of the localization of the core from the top of the mound can explain the presence of older dead coral fragments at the top of the core. This high mound growth in a relatively short time span $(85 \mathrm{~cm} / \mathrm{ka})$ shows that mound growth can go 
really fast when conditions are favorable. Core MD012452 learnt that most of the Magellan mounds were buried during glacial MIS 6. However, mound Perseverance seems to have survived this period of burial. The present-day situation in the Magellan mound province evidences of a quieter environment than the Belgica mound province. However, the Holocene toppart of core MD01-2452 is more pronounced as in core MD01-2450, where no typical foram-rich Holocene sands could be observed, characterizing the presence of stronger currents. Probably the currents are for the moment in the environment of Challenger mound too high preventing proper sediment deposition and even preventing proper coral growth, whereas in the Magellan mound province current strength seems to be localized in a window which is high enough to keep the polyps sediment-free and to supply enough nutrients but low enough to avoid destructive erosion. So, not only during recent times the sedimentological and oceanographic environment of the Magellan mound province and the Belgica mound province differ clearly having an important impact on coral and mound growth but also in the recent past some clear differences are noted.

Unit B, characterized by a section of altered corals, corresponds probably to the period before the onset of the Holocene, i.e. the last glacial period. This postulates, as observed on mound Challenger, that moundbuild up and cold-water coral growth could have been also occurred during glacial periods.

\section{Conclusion}

The study of both on-mound and off-mound cores by means of geophysical properties and X-ray imagery in respectively the Belgica and the Magellan mound province reveals some clear differences in the palaeoenvironmental setting of both provinces.

Core MD01-2450 in the sediments at the SW flank of Challenger Mound in the Belgica mound province bears evidence of a very dynamic environment, while core MD01-2452 above the buried Magellan mounds is evidencing less energetic palaeoenvironments. Significant glacial-interglacial variations have been identified in both cores, whereby stronger bottom currents probably due to the influence of MOW are responsible for the record of the characteristic coarser sediments deposited during interglacial periods. Six IRE, some of them with a poly-phased character probably due to a more rapid response of the BIIS on the external climatic forcing of Heinrich Events, could easily be recognized during the last glacial period.
The footprints of IRE are more pronounced in the susceptibility records going NW-ward, indicating the products of the Laurentide icebergs were losing intensity towards the Irish mainland or BIIS IRD diluted them.

Geophysical properties could clearly be correlated with X-ray imagery for the on-mound cores. Alternating units of coral-rich and coral-free sediments are observed, as well as layers with distinct coral alteration. The core on mound Challenger shows that this mound is now in a stage of retirement, whereby the cold-water corals are completely buried in three different cycles during the last glacial maximum. A reinitiating healthy bloom of cold-water coral growth could not be reached anymore during the Holocene. Probably nowadays currents are too strong for healthy coral growth. The Holocene record full of corals in the core on mound Perseverance evidences of a boost of cold-water corals during this period with a mound growth of $85 \mathrm{~cm} / \mathrm{ka}$. The presence of corals throughout the whole core suggests that mound-build up and cold-water coral growth could have also occurred during glacial periods. Not only during present times but also in the past both provinces, the Belgica Mound Province and the Magellan Mound Province show clear differences in their hydrodynamical environment, an observation that has an important impact on the assessment of sedimentation and mound growth.

Acknowledgements The authors would like to thank the captain, crew and shipboard parties of R/V Marion Dufresne (2001), R/V Belgica (1997-2001), R/V Pelagia (2002) and R/V Polarstern (2000). The IPEV and Yvon Balut are also thanked for the core acquisition and for logistic support. O. Weber, M. Cremer and J. Saint-Paul (DGO, Universite Bordeaux I) are acknowledged for their support with the SCOPIX analyses. The authors would also like to thank Dr. V. Huvenne and Dr. B. De Mol for their overall support during this research. This publication used TOBI side-scan sonar data and survey results acquired during a project undertaken with support of the European Union (EASSS III programme, 'Improving Human Potential', contract HPRICT-1999-00047) and on behalf of the Porcupine Studies Group (PSG) of the Irish Petroleum Infrastructure Programme Group 3. All the data have been acquired within the framework of the EC FP5 programs GEOMOUND and ECOMOUND. AF is a PhD student funded through a FWO Fellowship. DVR is a postdoctoral fellow funded by the FWO-Flanders.

\section{References}

Auffret GA, Zaragosi S, Dennielou B, Cortijo E, Van Rooij D, Grousset FE, Pujol C, Eynaud F, Siegert MJ, Paterne M (2002) Terrigenous fluxes at the Celtic margin during the last glacial cycle. Mar Geol 188:79-108

Berner RA (1970) Sedimentary pyrite formation. Am J Sci 267:19-42 
Berner RA (1984) Sedimentary pyrite formation: an update. Geochim Cosmochim Ac 48:605-615

Beyer A, Schenke HW, Klenke M, Niederjasper F (2003) High resolution bathymetry of the eastern slope of the Porcupine Seabight. Mar Geol 198:27-54

Bond $\mathrm{G}$, Hartmut $\mathrm{H}$, Broecker W, Labeyrie L, Mcmanus J, Andrews J, Huon S, Jantschik R, Clasen S, Simet C, Tedesco K, Klas M, Bonani G, Ivy S (1992) Evidence for massive discharges of icebergs into the North Atlantic ocean during the last glacial period. Nature 360:245-249

Broecker WS, Bond G, Klas M, Clark E, McManus J (1992) Origin of the Northern Atlantic's Heinrich Events. Clim Dyn 6:265-273

Cortijo E, Reynaud JY, Labeyrie L, Paillard D, Lehman B, Cremer M, Grousset F (1995) Étude de la variabilité climatique à haute résolution dans des sédiments de l'Atlantique Nord. CR Acad Sci Paris série IIa 321:231-238

Croker PF, Shannon PM (1987) The evolution and hydrocarbon prospectivity of the Porcupine Basin, Offshore Ireland. In: Brooks J, Glennie KW (eds) Petroleum geology of North West Europe. Graham \& Trotman, London, pp 632-642

Croker PF, Klemperer SL (1989) Structure and stratigraphy of the Porcupine Basin: relationships to depp crustal structure, the opening of the North Atlantic. In: Tankars AJ, Balkwill HR (eds) Extensional tectonics and stratigraphy of the North Atlantic margins. American Association of Petroleum Geologists, Tulsa, pp 445-459

De Haas H, Huvenne V, Wheeler A, Unnithan V, shipboard scientific crew (2002) A TOBI side scan sonar survey of cold water coral carbonate mounds in the rockall trough and Porcupine Sea Bight (R.V. Pelagia Cruise 64PE197)

De Mol B, Van Rensbergen P, Pillen S, Van Herreweghe K, Van Rooij D, McDonnell A, Huvenne V, Ivanov M, Swennen R, Henriet J-P (2002) Large deep-water coral banks in the Porcupine Basin, southwest of Ireland. Mar Geol 188:193231

Foubert A, Beck T, Wheeler AJ, Opderbecke J, Grehan A, Klages M, Thiede J, Henriet J-P, the Polarstern ARK-XIX/ 3a shipboard party (2005) New view of the Belgica Mounds, Porcupine Seabight, NE Atlantic: preliminary results from the Polarstern ARK-XIX/3a ROV cruise. In: Freiwald A, Roberts JM (eds) Cold-water coral and ecosystems. Springer, Berlin Heidelberg New York, pp 535-569

Frank N, Lutringer A, Paterne M, Blamart D, Henriet J-P, Van Rooij D, Van Weering TCE (2005) Deep-water corals of the northeastern Atlantic margin: carbonate mounds evolution, upper intermediate water ventilation during the Holocene. In: Freiwald A, Roberts JM (eds) Cold-water coral and ecosystems. Springer, Berlin Heidelberg New York, pp 113133

Freiwald A (2003) Reef-forming cold-water corals. In: Wefer G, Billett D, Hebbeln D, Jorgensen BB, Schlüter M, van Weering $\mathrm{T}$ (eds) Ocean margin systems. Springer, Berlin Heidelberg New York, pp 365-385

Grousset FE, Labeyrie L, Sinko JA, Cremer M, Bond G, Duprat J, Cortijo E, Huon S (1993) Patterns of ice-rafted detritus in the glacial North Atlantic $\left(40-55^{\circ} \mathrm{N}\right)$. Paleoceanography $8(2): 367-378$

Grousset FE, Pujol C, Labeyrie L, Auffret G, Boelaert A (2000) Were the North Atlantic Heinrich events triggered by the behavior of the European ice sheets? Geology 28:123-126

Grousset FE, Cortijo E, Huon S, Hervé L, Richter T, Burdloff D, Duprat J, Weber O (2001) Zooming in on Heinrich layers. Paleoceanography 16:240-259
Hargreaves PM (1984) The distribution of Decapoda (Crustacea) in the open ocean and near-bottom over an adjacent slope in the northern North-East Atlantic Ocean during Autumn 1979. J Mar Biol Assoc UK 64:829-857

Henriet J-P, De Mol B, Pillen S, Vanneste M, Van Rooij D, Versteeg W, Croker PF, Shannon PM, Unnithan V, Bouriak S, Chachkine P, Party TP-BS (1998) Gas hydrate crystals may help build reefs. Nature 391:648-649

Hovland M, Croker PF, Martin M (1994) Fault-associated seabed mounds (carbonate knolls?) off western Ireland and north-west Australia. Mar Petrol Geol 11(2):232-246

Huvenne V, Blondel P, Henriet J-P (2002) Current influences and mound appearance in the Porcupine Seabight: results from computer-assisted image analysis of sidescan sonar data. Mar Geol 189:323-341

Huvenne V, De Mol B, Henriet J-P (2003) A 3D seismic study of the morphology and spatial distribution of buried coral banks in the Porcupine Basin, SW of Ireland. Mar Geol 198:5-22

Huvenne VAI, Beyer A, de Haas H, Dekindt K, Henriet J-P, Kozachenko M, Olu-Le Roy K, Wheeler A, the TOBI/ Pelagia 197, CARACOLE cruise participants (2005) The seabed appearance of different coral bank provinces in the Porcupine Seabight, NE Atlantic: results from side-scan sonar and ROV seabed mapping. In: Freiwald A, Roberts JM (eds) Cold-water coral and ecosystems. Springer, Berlin Heidelberg New York, pp 535-569

Huvenne, VAI, Bailey WR, Shannon PM, Naeth J, Di Primio R, Henriet JP, Horsfield B, de Haas H, Wheeler A, Olu-Le Roy K (2006) The Magellan mound province in the Porcupine Basin. Int $\mathbf{J}$ Earth Sci (in press)

Karlin R, Levi S (1983) Diagenesis of magnetic minerals in recent hemipelagic sediments. Nature 303:327-330

Karlin R, Levi S (1985) Geochemical and sedimentological control of the magnetic properties of hemipelagic sediments. J Geophysl Res 90:10373-10392

Kenyon NH, Ivanov MK, Akhmetzhanov AM (1998) Cold water carbonate mounds and sediment transport on the Northeast Atlantic margin. IOC Technical Series 52, UNESCO, Paris

Le Danois E (1948) Les profondeurs de la mer. Payot, Paris, pp 1-303

Lofi J, Weber O (2001) SCOPIX_digital processing of X-ray images for the enhancements of sedimentary structures in undisturbed core slabs. Geo-Mar Lett 20:182-186

Maher B, Thompson R (1999) Quaternary climates, environments and magnetism. Cambridge University Press, Cambridge, pp 1-390

Martinson DG, Pisias NG, Hays JD, Imbrie J, Moore TC, Shackleton NJ (1987) Age dating and the orbital theory of the ice ages: development of a high-resolution 0 to 300.000year chronostratigraphy. Q Res 27:1-29

Migeon S, Weber O, Faugères J-C, Saint-Paul J (1999) SCOPIX: a new X-ray imaging system for core analysis. Geo-Mar Lett 18:251-255

Moore JG, Shannon PM (1992) Paleocene-Eocene deltaic sedimentation, Porcupine Basin, offshore Ireland-a sequence stratigraphic approach. First break 10(12):461469

Naylor D, Shannon PM (1982) The geology of offshore reland and West Britain. Graham \& Trotman ltd., London

New AL, Barnard S, Herrmann P, Molines J-M (2001) On the origin and pathway of the saline inflow to the Nordic Seas: insights from models. Prog Oceanogr 48:255-287

Pingree RD, Le Cann B (1989) Celtic and Armorican slope and shelf residual currents. Prog Oceanogr 23:303-338 
Pingree RD, Le Cann B (1990) Structure, strength and seasonality of the slope currents in the Bay of Biscay region. J Mar Biol Assoc UK 70:857-885

Rice AL, Billet DSM, Thurston MH, Lampitt RS (1991) The institute of oceanographic sciences biology programme in the Porcupine Seabight: background and general introduction. J Mar Biol Assoc UK 71:281-310

Richter TO, Lassen S, van Weering TCE, de Haas H (2001) Magnetic susceptibility patterns and provenance of ice-rafted material at Feni Drift, Rockall Trough: implications for the history of the British-Irish ice sheet. Mar Geol 173:37-54

Roberts AP (1995) Magnetic properties of sedimentary Greigite $\left(\mathrm{Fe}_{3} \mathrm{~S}_{4}\right)$. Earth Planet Sc Lett 134:227-236

Robinson SG, Maslin MA, McCave IN (1995) Magnetic susceptibility variations in Upper Pleistocene deep-sea sediments of the NE Atlantic: Implications for ice rafting and paleocirculation at the last glacial maximum. Paleoceanoghraphy 10:221-250

Ruddiman WF (1977) Late quaternary deposition of ice-rafted sand in the subpolar North Atlantic (lat $40^{\circ}$ to $65^{\circ} \mathrm{N}$ ). Geol soc Am Bull 88:1813-1827

Schonfeld J, Zahn R (2000) Late glacial to Holocene history of Mediterranean Outflow. Evidence from benthic foraminiferal assemblages and stable isotopes at the Portuguese margin. Palaeogeogr Paleocl 159:85-111

Scourse JD, Hall IR, McCave IN, Young JR, Sugdon C (2000) The origin of Heinrich layers: evidence from $\mathrm{H} 2$ for European precursor events. Earth Planet Sci Lett 182:187-195

Skinner LC, McCave IN (2003) Analyses and modelling of gravity- and piston coring based on soil mechanics. Mar Geol 199:181-204

Snoeckx H, Grousset F, Revel M, Boelaert A (1999) European contribution of ice-rafted sand to Heinrich layers $\mathrm{H} 3$ and H4. Mar Geol 158:197-208

Thierens M (2005) A palaeo-oceanographic study of late-quaternary sediments based on foraminifers and coccoliths north of Porcupine Seabight, south-west off Ireland. MSc Thesis, University Gent, pp 1-155
Thompson R, Oldfield F (1986) Environmental magnetism. Allen \& Unwin, London, pp 1-277

Thomson CW (1873) The depths of the sea. Macmillan, London Thouveny N, de Beaulieu J-L, Bonifay E, Creer KM, Guiot J, Icole M, Johnsen S, Jouzel J, Reille M, Trevor W, Williamson D (1994) Climate variations in Europe over the past $140 \mathrm{kyr}$ deduced from rock magnetism. Nature 371:503-506

Thouveny N, Moreno E, Delanghe D, Candon L, Lancelot Y, Shackleton NJ (2000) Rock magnetic detection of distal ice-rafted debries: clue for the identification of Heinrich layers on the Portuguese margin. Earth Planet Sci Lett 180:61-75

Tribble GW (1993) Organic matter oxidation and aragonite diagenesis in a coral reef. J Sediment Petrol 63:523-527

Van Rooij D, De Mol B, Huvenne V, Ivanov M, Henriet JP (2003) Seismic evidence of current-controlled sedimentation in the Belgica mound province, southwest of Ireland. Mar Geol 195(1-4):31-53

Van Rooij D, Blamart D, Richter T, Wheeler A, Kozachenko M, Henriet J-P (2006) Quaternary sediment dynamics in the Belgica mound province, Porcupine Seabight: Ice rafting events and contour current processes. Int $\mathbf{J}$ Earth Sci (in press)

Wheeler AJ, Kozachenko M, Beyer A, Foubert A, Huvenne VAI, Klages M, Masson DG, Olu-Le Roy K., Thiede J (2005) Sedimentary Processes and Carbonate Mounds in the Belgica mound province, Porcupine Seabight, NE Atlantic. In: Freiwald A, Roberts JM (eds) Cold-water coral and ecosystems. Springer, Berlin Heidelberg New York, pp 571603

White M (2001) Hydrography and physical dynamics at the NE Atlantic margin that influence the deep-water cold coral reef ecosystem. Department of Oceanography, NUI Galway, Ireland, pp 1-31

White M (2006) The hydrographic setting for the carbonate mounds of the Porcupine Bank and Sea Bight. Int J Earth Sci (in press) 